\title{
THE INFLUENCE OF GREEN MARKETING ON GREEN SATISFACTION MEDIATED BY PERCEIVED QUALITY AND ITS IMPACT TO GREEN TRUST IN INJECTION MOTORCYCLE
}

\author{
Shelvy Kurniawan \\ School of Business Management, Bina Nusantara University \\ Jln. K.H. Syahdan No. 9, Palmerah, Jakarta Barat 11480 \\ shelvy_kurniawan2402@yahoo.com
}

\begin{abstract}
Currently, motorcycle manufacturers are increasingly motivated to replace their motorcycle into fuel injection products. The growing concern from the consumers to the environment and the regulations of emission standards, that is Euro 3, for motorcycle industry is being finalized in the Ministry of Environment in order to be implemented in Indonesia. Through this research, the writer will examine the effect of green marketing on perceived quality, green satisfaction, and green trust, the effect of perceived quality on green satisfaction, and the effect of green satisfaction on green trust. Those effects needs to be investigated in order to know how far the effects of green marketing and to ensure whether green marketing is well accepted or not by the market in motorcycle industry. Scope of this research is also limited to the user of fuel injection motorcycle in Jakarta for Honda and Yamaha who involved as decision maker when the motorcycle is purchased. Sampling technique used in this research is quota sampling and the analysis method is structural equation modeling (SEM). The findings of this research are: green marketing has a significant direct effect on perceived quality, perceived quality has a significant direct effect on green satisfaction, green satisfaction has a significant direct effect on green trust, green marketing has a significant direct and indirect effect on green satisfaction, and green marketing has a significant direct and indirect effect on green trust. All of those effects are found to be positive effects.
\end{abstract}

Keywords: green marketing, perceived quality, satisfaction, trust

\begin{abstract}
ABSTRAK
Saat ini produsen sepeda motor makin termotivasi untuk menggantikan sepeda motor mereka menjadi produk injeksi. Berkembangnya perhatian dari konsumen terhadap lingkungan dan peraturan standar emisi, Euro 3, untuk industri sepeda motor sedang diselesaikan di Kementerian Lingkungan Hidup untuk diimplementasikan di Indonesia. Melalui penelitian ini, penulis menguji pengaruh green marketing pada persepsi kualitas, green satisfaction, dan green trust; pengaruh persepsi kualitas terhadap green satisfaction; dan pengaruh green satisfaction pada green trust. Efek tersebut perlu diteliti untuk mengetahui sejauh mana pengaruh green marketing dan untuk memastikan apakah green marketing diterima dengan baik atau tidak oleh pasar di industri sepeda motor. Lingkup penelitian ini juga terbatas pada pengguna sepeda motor injeksi di Jakarta untuk Honda dan Yamaha yang terlibat sebagai pengambil keputusan ketika sepeda motor mereka dibeli. Teknik yang digunakan dalam penelitian ini adalah quota sampling dan metode analisis adalah model persamaan struktural (SEM). Temuan dari penelitian ini adalah green marketing memiliki pengaruh langsung yang signifikan terhadap persepsi kualitas; persepsi kualitas memiliki pengaruh langsung yang signifikan terhadap green satisfaction; green satisfaction memiliki pengaruh langsung yang signifikan terhadap green trust; green marketing memiliki pengaruh langsung dan tidak langsung yang signifikan terhadap green satisfaction; dan green marketing memiliki pengaruh langsung dan tidak langsung yang signifikan terhadap green trust. Semua pengaruh yang ditemukan tersebut adalah pengaruh yang bersifat positif.
\end{abstract}

Kata kunci: green marketing, persepsi kualitas, kepuasan, kepercayaan 


\section{INTRODUCTION}

In current era, concern for the environment is increasing from time to time where it also contributes to the growing trend of green marketing, including the creation of environmentally friendly products. The growing trend of green marketing is supported by Tiwari, Tripathi, Srivastava, \& Yadav (2011) which stated, "There is growing interest among the consumers all over the world regarding protection of environment. Worldwide evidence indicates people are concerned about the environment and are changing their behavior. As a result of this, green marketing has emerged which speaks for growing market for sustainable and socially responsible products and services”.

Green marketing in motorcycle industry is visible from the emergence of fuel injection motorcycle. Motorcycle manufacturers are increasingly motivated to replace their motorcycle into fuel injection products, because the regulations of emission standards, that is Euro 3, for motorcycle industry is being finalized in the Ministry of Environment in order to be implemented in Indonesia, where Euro 3 is one solution to minimize environmental pollution (AISI, 2012), and injection motorcycle can be the solution for motorcycle industry in reducing emissions to the environment (Astra-Honda, 2012).

Currently, the dominant players in motorcycle industry are Honda and Yamaha, where both of them takes 92\% from total market (both injection and carburetor) Jan-Aug 2012 (AISI, 2012). The wholesales of injection motorcycle of two dominant players in motorcycle industry (Honda and Yamaha) are shown in Table 1. From that number, currently the fuel injection wholesales of Honda and Yamaha is only about 30\% from their total wholesales.

Table 1 Fuel Injection Wholesales in 2012 between Honda and Yamaha

\begin{tabular}{cccc}
\hline Brand & $\begin{array}{c}\text { Fuel Injection } \\
\text { (Jan-Aug 2012) }\end{array}$ & $\begin{array}{c}\text { Fuel Injection + Carburetor } \\
\text { (Jan-Aug 2012) }\end{array}$ & $\begin{array}{c}\text { Fuel Injection/ } \\
\text { Total Wholesales }\end{array}$ \\
\hline Honda & 565,953 & $2,707,804$ & $21 \%$ \\
Yamaha & 753,427 & $1,629,026$ & $46 \%$ \\
Total & $1,319,380$ & $4,336,830$ & $30 \%$ \\
\hline
\end{tabular}

Source: AISI (2012)

The researcher argued that how consumers perceive the quality of green marketing is essential to be investigated in order to determine whether the implementation of green marketing is well accepted or not. The researcher will investigate, The Influence of Green Marketing on Green Satisfaction which is Mediated by Perceived Quality and Its Impact to Green Trust in Injection Motorcycle. Honda and Yamaha as the dominant players in motorcycle industry will be studied to represent the motorcycle industry. Moreover, scope of this research is also limited to the user of fuel injection motorcycle in Jakarta who involved as decision maker when the motorcycle is purchased.

The researcher will examine the effect of green marketing on perceived quality, green satisfaction, and green trust, the effect of perceived quality on green satisfaction, and the effect of green satisfaction on green trust. Those effects needs to be investigated in order to ensure whether green marketing is well accepted or not by the market in motorcycle industry. 


\section{Literature Review}

\section{Green Marketing}

According to Wang \& Tung (2012), “The biggest difference between green and traditional marketing is that in green marketing, the needs and principles of environmental protection are considered in the marketing $4 \mathrm{P}$ activities, to satisfy the demands of society and consumers", then Bhattacharya (2011) explained, "Conventional marketing has self-centered approach, while green marketing has a social cost-benefit approach inclined towards environmental conservation". Polanski (1994 as cited in Tiwari, Tripathi, Srivastava, \& Yadav, 2011) explained, "Green or Environmental Marketing consists of all activities designed to generate and facilitate any exchanges intended to satisfy human needs or wants, such that the satisfaction of these needs and wants occurs, with minimal detrimental impact on the natural environment".

Based on previous explanation about green marketing, the researcher defines green marketing as implementation of marketing mix elements by considering green factor in order to fulfill consumer's needs and wants to minimize harmful impact on the environment which is caused by its marketing activities. Green marketing in this research is measured by marketing mix elements. In this research, the researcher is going to investigate marketing mix for product category which consist of $4 \mathrm{P}$ elements: product, price, place, and promotion (McCarthy as cited in Kotler \& Keller, 2012).

\section{Perceived Quality}

According to American Society for Quality, "Quality is the totally of features and characteristics of a product or service that bear on its ability to satisfy stated or implied needs" (Kotler \& Keller, 2012). Mitra \& Golder (2006) explained, "Perceived quality is the overall subjective judgment of quality relative to the expectation of quality". Based on previous explanation, the researcher defines perceived quality as the consumer evaluations of the quality of a product that can reflect how well a product doing its function, because it is the perception of the consumer, so the result will be subjective and differ from one consumer with other consumers. Furthermore, perceived quality is subjective, because assessments can be influenced by the expectations, needs and consumption situations which differ from one person to another.

Aaker (1991) explained that related to product quality while Garvin (1984), suggests seven product quality dimensions which consists of performance, features, conformance, reliability, durability, serviceability, fit and finish.

\section{Satisfaction}

According to Kotler \& Keller (2012), "Satisfaction reflects a person’s judgment of a product's perceived performance in relationships to expectations". Chen (2010) in his research proposed a novel construct of satisfaction, that is green satisfaction and defined it as "a pleasurable level of consumption-related fulfillment to satisfy a customer's environmental desires, sustainable expectations, and green needs"'.

Satisfaction is defined as how pleased consumers towards the performance which the consumer obtain from a product to meet needs and wants of the consumer, furthermore, in the context of green satisfaction, environmental friendly factor will be the basis for assessing whether a consumer is satisfied or not towards a product. The measurement of green satisfaction used by Chen (2010) consists of four items, they are includes: "(1) You are happy about the decision to choose this brand because of its environmental commitments; (2) You believe that it is a right thing to purchase this brand because of its environmental performance; (3) Overall, you are glad to buy this brand because it is environmental friendly; and (4) Overall, you are satisfied with this brand because of its environmental concern”. 


\section{Trust}

Zboja and Voorhees (2006) explained that trust exists, "when one party has confidence in an exchange partner's reliability and integrity". Hart and Saunders (1997 as cited in Chen, 2010) stated, "Trust is a level of the confidence that another party would behave as expected". Delgado-Ballester (2004) explained, "Brand trust is conceptualized as the confident expectation of the brand's reliability and intentions in situations entailing risk to the consumer". Chen (2010) in his research proposed a novel construct of trust, that is green trust and defined it as "a willingness to depend on a product, service, or brand based on the belief or expectation resulting from its credibility, benevolence, and ability about its environmental performance’”.

Based on previous explanation, the researcher defines brand trust as belief that a brand has ability and desire to fulfill what has been promised and has intention to always be ready to serve the needs of customers, including when there are problems associated with the use of the brand, furthermore, in the context of green trust which will be studied in this research, environmental friendly factor will be the basis for assessing whether a consumer is trust or not towards a product.

Discussing trust in relation to green concept or what being called as green trust, it is measured through five items of question (Chen, 2010), they are includes: “(1) You feel that this brand's environmental commitments are generally reliable; (2) you feel that this brand's environmental performance is generally dependable; (3) you feel that this brand's environmental argument is generally trustworthy; (4) This brand's environmental concern meets your expectations; and (5) This brand keeps promises and commitments for environmental protection”.

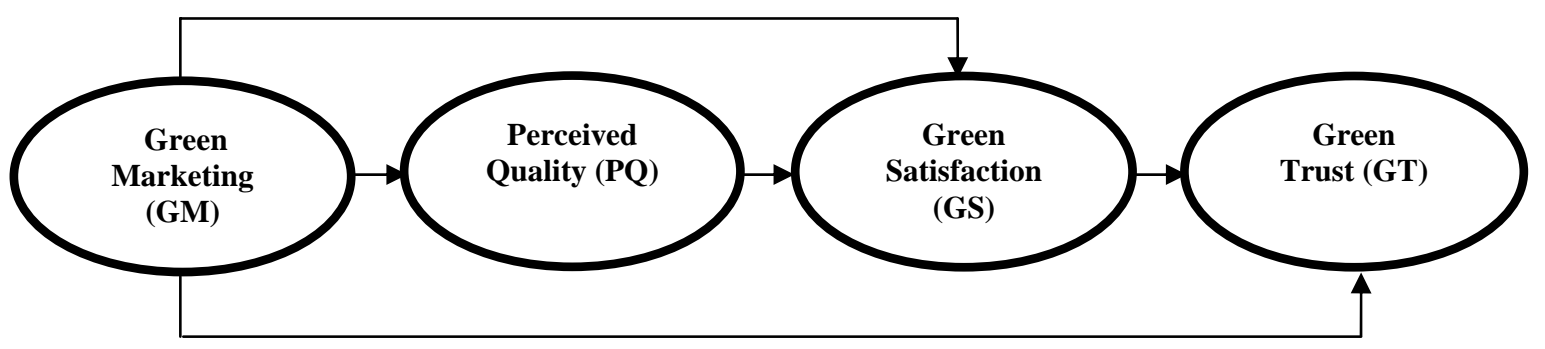

Figure 1 Theoretical Framework Source: The writer (2012)

\section{METHOD}

This study is descriptive study. Unit of analysis in this study is the individual, they are the users of fuel injection motorcycle who participating in decision-making when the bike was purchased. Time horizon for the study is cross-sectional. The researcher uses both primary and secondary data. Data collection method used in this study is through literature search and questionnaire. The sampling design used in this study is quota sampling. The sample size used in this study is determined based on several considerations in determining the sample size in structural equation modeling (SEM). According to Kelloway and Marsh et. al., the sample size for SEM is at least 200 observations (Riduwan and Kuncoro, 2008). Then, Joreskog and Sorbom explained about the minimum sample size needed in structural equation based on number of variables researched as stated in Table 2. 
Table 2 Minimum Sample Size and Number of Variables

\begin{tabular}{cc}
\hline Number of Variables & Minimum Sample Size \\
\hline 3 & 200 \\
5 & 200 \\
10 & 200 \\
15 & 360 \\
20 & 630 \\
25 & 975 \\
30 & 1395 \\
\hline
\end{tabular}

Source: Riduwan and Kuncoro (2008)

In this research, The researcher studies four variables, they are green marketing, perceived quality, green satisfaction, and green trust. Based on information in Table 2, the sample size which is needed is 200 samples. In addition, this research will use structural equation modeling with Maximum Likelihood as the method if the normality assumption is fulfilled or Robust Maximum Likelihood to correct non normal data. According to Hair et. Al, the minimum sample size used in Maximum Likelihood is around 100-200 samples (Ghozali and Fuad, 2008). Based on several previous considerations, 200 samples will be used for this research. The quota is based on the fuel injection wholesales of Honda and Yamaha from January to August 2012. The quota is presented in Table 3.

Table 3 Samples Composition

\begin{tabular}{|l|r|c|r|}
\hline \multirow{2}{*}{ Brand } & \multicolumn{2}{|c|}{ \% FI Distribution Jan-Aug 2012 } & \multirow{2}{*}{ Samples } \\
\cline { 2 - 3 } & Volume & $\mathbf{\%}$ & \\
\hline Honda & 565953 & $42.90 \%$ & 86 \\
\hline Yamaha & 753427 & $57.10 \%$ & 114 \\
\hline Total & 1319380 & & 200 \\
\hline
\end{tabular}

Source: The Researcher (2012)

Structural Equation Modeling (SEM) in this study will be processed using Linear Structural Relationship (LISREL).

\section{RESULTS AND DISCUSSION}

\section{Analysis of Structural Equation 1}

$$
\mathrm{PQ}=0.59 * \mathrm{GM}, \text { Errorvar. }=0.65, \mathrm{R}^{2}=0.35
$$

Hypothesis 1: Green marketing has a significant direct effect on perceived quality

T-value $=5.63>1.96$, so green marketing has a significant direct effect on perceived quality. It can be observed that it is a positive effect with the positive sign in front of t-value (5.63). Estimation value of 
0.59 means that if there is an increase in the assessment of green marketing by one unit, then the assessment of perceived quality will increase by 0.59 .

\section{Analysis of Structural Equation 2}

$$
\mathrm{GS}=\begin{array}{ccc}
0.45^{*} \mathrm{PQ} & +0.51^{*} \mathrm{GM}, \text { Errorvar. }= & 0.26, \mathrm{R}^{2}=0.74 \\
(0.083) & (0.084) & (0.052) \\
5.45 & 6.12 & 4.96
\end{array}
$$

Hypothesis 2: Perceived quality has a significant direct effect on green satisfaction

T-value $=5.45>1.96$, so perceived quality has a significant direct effect on green satisfaction. It can be observed that it is a positive effect with the positive sign in front of t-value (5.45. Estimation value of 0.45 means that if there is an increase in the assessment of perceived quality by one unit, then the assessment of green satisfaction will increase by 0.45 .

Hypothesis 3: Green marketing has a significant direct effect on green satisfaction

T-value $=6.12>1.96$, so green marketing has a significant direct effect on green satisfaction. It can be observed that it is a positive effect with the positive sign in front of t-value (6.12). Estimation value of 0.51 means that if there is an increase in the assessment of green marketing by one unit, then the assessment of green satisfaction will increase by 0.51 .

$\mathrm{R}^{2}=0.74$ means that green marketing and perceived quality together affecting green satisfaction by $74 \%$ and the other $26 \%$ were influenced by other variables outside of the study.

\section{Analysis of Structural Equation 3}

$$
\begin{aligned}
& \mathrm{GT}=0.72 * \mathrm{GS}+0.21 * \mathrm{GM} \text {, Errorvar. }=0.21, \mathrm{R}^{2}=0.79 \\
& (0.098) \quad(0.10) \quad(0.056) \\
& \begin{array}{lll}
7.27 & 2.08 & 3.74
\end{array}
\end{aligned}
$$

Hypothesis 4 : Green satisfaction has a significant direct effect on green trust

T-value $=7.27>1.96$, so green satisfaction has a significant direct effect on green trust. It can be observed that it is a positive effect with the positive sign in front of t-value (7.27). Estimation value of 0.72 means that if there is an increase in the assessment of green satisfaction by one unit, then the assessment of green trust will increase by 0.72 .

Hypothesis 5 : Green marketing has a significant direct effect on green trust

T-value $=2.08>1.96$, so green marketing has a significant direct effect on green trust. It can be observed that it is a positive effect with the positive sign in front of t-value (2.08). Estimation value of 0.21 means that if there is an increase in the assessment of green marketing by one unit, then the assessment of green trust will increase by 0.21 .

$\mathrm{R}^{2}=0.79$ means that green marketing and green satisfaction together affecting green trust by $79 \%$ and the other $21 \%$ were influenced by other variables outside of the study. 
Table 4 Indirect Effect

\begin{tabular}{cc}
\hline Latent Variable & Green Marketing \\
\hline \multirow{2}{*}{ Green Satisfaction } & 0.27 \\
& $(0.06)$ \\
& 4.17 \\
Green Trust & 0.56 \\
& $(0.10)$ \\
\hline
\end{tabular}

Source: The Researcher (2012)

Hypothesis 6 : Green marketing has a significant indirect effect on green satisfaction

$\mathrm{T}$-value $=4.17>1.96$, so green marketing has a significant indirect effect on green satisfaction. It can be observed that it is a positive effect with the positive sign in front of t-value (4.17). Estimation value of 0.27 means that if there is an increase in the assessment of green marketing by one unit, then the assessment of green satisfaction will increase by 0.27 .

Hypothesis 7 : Green marketing has a significant indirect effect on green trust

$\mathrm{T}$-value $=5.78>1.96$, so green marketing has a significant indirect effect on green trust. It can be observed that it is a positive effect with the positive sign in front of t-value (5.78). Estimation value of 0.56 means that if there is an increase in the assessment of green marketing by one unit, then the assessment of green trust will increase by 0.56 .

Based on previous hypotheses testing, the researcher produces the following analysis: (1) Total effect of green marketing on the green satisfaction is 0.78 , where the value is the sum of direct effect (0.51) and indirect effect (0.27) of green marketing on green satisfaction. (2) Total effect of green marketing on the green trust is 0.77 , where the value is the sum of direct effect $(0.21)$ and indirect effect (0.56) of green marketing on green trust.

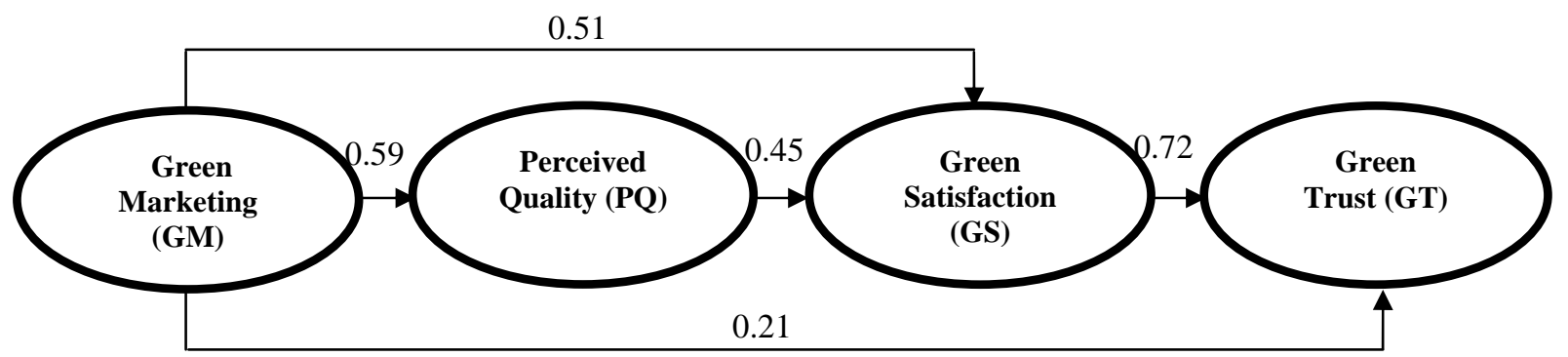

Figure 2 Effect of Green Satisfaction on Green Trust Source: The Researcher (2012) 
in Table 5.

The score of the questionnaire which is collected by the researcher for each indicator is stated

Table 5 Questionnaire’s Score

\begin{tabular}{|c|c|c|}
\hline No. & Questionnaire & Score \\
\hline \multicolumn{3}{|c|}{ Green Marketing } \\
\hline 1. & My fuel injection motorcycle reduces pollution to the environment & 3.86 \\
\hline 2. & $\begin{array}{l}\text { My fuel injection motorcycle produces little gas emissions than carburetor motorcycle in its } \\
\text { class }\end{array}$ & 3.99 \\
\hline 3. & My fuel injection motorcycle has affordable price & 3.67 \\
\hline 4. & The price of my fuel injection motorcycle is proportionate with its quality & 3.91 \\
\hline 5. & I can find dealers who sell my fuel injection motorcycle easily & 4.06 \\
\hline 6. & I can find dealers which provide maintenance for my fuel injection motorcycle easily & 3.82 \\
\hline 7. & $\begin{array}{l}\text { When making a purchase, I can get my fuel injection motorcycle easily because the dealer has } \\
\text { inventory to be sold }\end{array}$ & 3.74 \\
\hline 8. & $\begin{array}{l}\text { The motorcycle company holds seminars or conferences related to the technology of fuel } \\
\text { injection motorcycle }\end{array}$ & 3.11 \\
\hline & $\begin{array}{l}\text { The company/dealer advertises fuel injection motorcycle more intensive than carburetor } \\
\text { motorcycle, either through brochures, television, etc }\end{array}$ & 3.83 \\
\hline 10. & $\begin{array}{l}\text { Sales force of dealers direct me to buy fuel injection motorcycle by promoting it as } \\
\text { environmentally friendly products }\end{array}$ & 3.75 \\
\hline \multicolumn{3}{|c|}{ Perceived Quality } \\
\hline 11. & My fuel injection motorcycle is more powerful carburetor motorcycle in its class & 3.53 \\
\hline 12. & $\begin{array}{l}\text { My fuel injection motorcycle is more efficient in fuel usage than carburetor motorcycle in its } \\
\text { class }\end{array}$ & 3.96 \\
\hline & $\begin{array}{l}\text { Features offered in my fuel injection motorcycles are not inferior to others motorcycle in the } \\
\text { same class }\end{array}$ & 3.97 \\
\hline 14. & In my opinion, I do not find any defects in my fuel injection motorcycle & 3.70 \\
\hline 15. & My fuel injection motorcycle has reliable performance even though using premium fuel & 3.82 \\
\hline 16. & My fuel injection motorcycle is durable motorcycle & 3.72 \\
\hline & The maintenance of my fuel injection motorcycle can be done easily & 3.47 \\
\hline 18. & My fuel injection motorcycle is a quality motorcycle & 4.03 \\
\hline \multicolumn{3}{|c|}{ Green Satisfaction } \\
\hline & $\begin{array}{l}\text { I am happy about the decision to choose this product because of its environmental } \\
\text { commitments }\end{array}$ & 3.91 \\
\hline & $\begin{array}{l}\text { In my opinion, it is a right thing to purchase this product because of its better environmental } \\
\text { effects }\end{array}$ & 4.01 \\
\hline 21. & Overall, I am glad to buy this product because it is environmental friendly & 4.03 \\
\hline 22. & Overall, I am satisfied with this product because of its environmental concern & 4.10 \\
\hline \multicolumn{3}{|c|}{ Green Trust } \\
\hline & This brand’s environmental commitments are generally reliable & 4.02 \\
\hline & This environmental brand's performance is generally dependable & 4.06 \\
\hline & I am trust with this brand's environmental campaign & 4.01 \\
\hline 26. & This brand's environmental concern meets my expectations & 3.99 \\
\hline & $\begin{array}{l}\text { The company which produces my fuel injection motorcycle always keeps promises and } \\
\text { commitments for environmental protection }\end{array}$ & 3.86 \\
\hline
\end{tabular}

Source: The Researcher (2012) 
By observing the value given by the respondents to the implementation of green marketing in relation to fuel injection motorcycle, the researcher finds that the lowest score fell into the assessment of the agreement that the company or dealer held seminars or conferences related to fuel injection motorcycle technology where it seems that consumers tend to judge neutral to that statement. According to the researcher's observation, the companies in motorcycle industry, has carried out seminars related injection motors, but tend to reach out to a specific community, such as journalists, bloggers, or motorcycle clubs, so it is possible that the respondents in this study is not yet reachable by seminars related to fuel injection motorcycle.

In relation to the perceived quality variable, the lowest rating given by consumers falls on the maintenance of fuel injection motorcycle which can be done easily. This indicates that consumers have not fully agreed for the ease of fuel injection motorcycle maintenance. Discussing about satisfaction \& trust of injection motorcycle, the researcher found that the respondents agreed that they are satisfy with green factors in fuel injection motorcycle, where the average point given by the respondents is 4.0125 (average score from 4 indicators). The same finding also found in green trust variable, where the average score of five indicators of green trust given by the respondent is 4.006, this indicates that they are at agreed level that they believe to environmentally friendly nature of fuel injection motorcycle.

\section{CONCLUSION}

Green marketing has a significant direct effect on perceived quality, perceived quality has a significant direct effect on green satisfaction, green satisfaction has a significant direct effect on green trust, green marketing has a significant direct and indirect effect on green satisfaction, and green marketing has a significant direct and indirect effect on green trust. All of those effects are found to be positive effects.

For green marketing mix variable, the lowest rating is fall into the statement that the company or dealer held seminars or conferences related to fuel injection motorcycle technology. For perceived quality variable, the lowest rating is fall into the statement that the maintenance of fuel injection motorcycle which can be done easily. From the assessment of green satisfaction and green trust indicator, the researcher finds that users are on agree level that they are satisfy and believe to environmentally friendly nature of fuel injection motorcycle.

By observing on the lowest rating given to green marketing indicator that is to the agreement that the company or dealer held seminars or conferences related to fuel injection motorcycle technology, the researcher propose that motorcycle industry needs to be more intense in conducting seminar or training related to injection motorcycle. In relation to the seminar or training which is proposed to be conducted to be more intense in previous point, the researcher propose that the seminar or training should be more emphasize on the ease of maintenance of the motor by considering that the respondent still gave the lowest score for ease of maintenance in perceived quality variable.

Future research can apply this research in different scope of study, for example in different coverage area.This research topic can be investigated again as comparative study among different brands. Furthermore, the result can be not only for a reference of comparative study among different brands, but also can be compared to industry results. Because motorcycle is included as high involvement products, future research can study the same topic in low involvement products in order to compare the effects resulted by green marketing. If the result is the same, so the effect of green marketing to perceived quality, green satisfaction, and green trust can be generalized for the body of knowledge in marketing. 
Future research can also be done to ensure whether the significance effect of green marketing to perceived quality, green satisfaction, and green trust, can influence the users to do word of mouth of the products, because green products is just beginning to evolve, so it can be very useful if injection motorcycle can get positive word of mouth.

\section{REFERENCES}

Aaker, D. A. (1991). Managing Brand Equity: Capitalizing on the Value of a Brand Name. New York: Simon \& Schuster Inc.

Asosiasi Industri Sepeda Motor Indonesia (AISI). (2012). Acara Diskusi Interaktif "Kesiapan Industri Sepeda Motor Indonesia Menuju Standar Euro-3 yang Ramah Lingkungan dan Hemat BBM”. Retrieved July 7, 2012, from http://www.aisi.or.id/news/detail/read/acara-diskusi-interaktifkesiapan-industri-sepeda-motor-indonesia-menuju-standar-euro-3-yang-rama/

Asosiasi Industri Sepeda Motor Indonesia (AISI). (2012). Statistic: Motorcycle Production Wholesales Domestic and Exports. Retrieved July 7, 2012 from http://www.aisi.or.id/statistic/

Astra-Honda. (2012). AHM Luncurkan The All New Honda BeAT-FI. Retrieved October 15, 2012, from http://www.astra-honda.com/index.php/berita/view/446

Bhattacharya, S. (2011). Consumer attitude towards green marketing in India. The IUP Journal of Marketing Management, 10(4), 62-71.

Chen, Y. (2010). The drivers of green brand equity: Green brand image, green satisfaction, and green trust. Journal of Business Ethics, 93, 307-319.

Delgado-Ballester, E. (2004). Applicability of a brand trust scale across product categories a multigroup invariance analysis. European Journal of Marketing, 38(5/6), 573-592.

Ghozali, I. \& Fuad. (2008). Structural Equation Modeling: Teori, Konsep, dan Aplikasi dengan Program Lisrel 8.80. Semarang: Universitas Diponegoro.

Garvin, D. A. (1984). What does "product quality” really mean? Sloan Management Review, 26(1), $25-43$.

Kotler, P., \& Keller, K. L. (2012). Marketing Management. Fourteenth edition. England: Pearson Education Limited.

Mitra, D., \& Golder, P. N. (2006). How does objective quality affect perceived quality? Short-term effects, long-term effects, and asymmetries. Marketing Science, 25(3), 230-291.

Riduwan, \& Kuncoro, E. A. (2008). Cara Menggunakan dan Memakai Analisis Jalur (Path Analysis). Bandung: Alfabeta.

Tiwari, S, Tripathi, D. M., Srivastava, U., \& Yadav, P. K. (2011). Green marketing-emerging dimensions. Journal of Business Excellence, 2(1), 18-23.

Wang, W. L., \& Tung, L. (2012). Most feasible strategies for green marketing mix under business sustainable development. The Business Review, Cambridge, 20(1), 297-303.

Zboja, J. J., \& Voorhees, C. M. (2006). The impact of brand trust and satisfaction on retailer repurchase intentions. Journal of Service Marketing, 20(5), 381-390. 